\title{
Exposure to fine and ultrafine particles from secondhand smoke in public places before and after the smoking ban, Italy 2005
}

\author{
Pasquale Valente, Francesco Forastiere, Antonella Bacosi, Giorgio Cattani, Simonetta Di Carlo, \\ Monica Ferri, Irene Figà-Talamanca, Achille Marconi, Luigi Paoletti, Carlo Perucci, Piergiorgio \\ Zuccaro
}

See end of article for authors' affiliations

Correspondence to: Pasquale Valente, Istituto Superiore di Sanità Dipartimento Tecnologie e Salute, Viale Regina Elena 299, 00168 Roma: pasquale.valente@iss.it

Received 14 December 2006 Accepted 4 May 2007

\begin{abstract}
Background: A smoking ban in all indoor public places was enforced in Italy on 10 January 2005.
Methods: We compared indoor air quality before and after the smoking ban by monitoring the indoor concentrations of fine $\left(<2.5 \mu \mathrm{m}\right.$ diameter, $\left.\mathrm{PM}_{2.5}\right)$ and ultrafine particulate matter $(<0.1 \mu \mathrm{m}$ diameter, UFP). $\mathrm{PM}_{2.5}$ and ultrafine particles were measured in 40 public places (14 bars, six fast food restaurants, eight restaurants, six game rooms, six pubs) in Rome, before and after the introduction of the law banning smoking (after 3 and 12 months). Measurements were taken using real time particle monitors (DustTRAK Mod. 8520 TSI; Ultra-fine Particles Counter-TRAK Model 8525 TSI). The PM 2.5 data were scaled using a correction equation derived from a comparison with the reference method (gravimetric measurement). The study was completed by measuring urinary cotinine, and pre-law and post-law enforcement among non-smoking employees at these establishments

Results: In the post-law period, $\mathrm{PM}_{2.5}$ decreased significantly from a mean concentration of $119.3 \mu \mathrm{g} / \mathrm{m}^{3}$ to $38.2 \mu \mathrm{g} / \mathrm{m}^{3}$ after 3 months $(p<0.005)$, and then to $43.3 \mu \mathrm{g} / \mathrm{m}^{3}$ a year later $(\mathrm{p}<0.01)$. The UFP concentrations also decreased significantly from 76956 particles $/ \mathrm{cm}^{3}$ to 38079 particles $/ \mathrm{cm}^{3}(p<0.0001)$ and then to 51692 particles $/ \mathrm{cm}^{3}(\mathrm{p}<0.01)$. Similarly, the concentration of urinary cotinine among nonsmoking workers decreased from $17.8 \mathrm{ng} / \mathrm{ml}$ to $5.5 \mathrm{ng} / \mathrm{ml}(\mathrm{p}<0.0001)$ and then to $3.7 \mathrm{ng} / \mathrm{ml}(\mathrm{p}<0.0001)$. Conclusion: The application of the smoking ban led to a considerable reduction in the exposure to indoor fine and ultrafine particles in hospitality venues, confirmed by a contemporaneous reduction of urinary cotinine.
\end{abstract}

$\mathrm{T}$ he application of the law banning smoking in indoor public places in Italy on 10 January $2005^{1}$ follows other smoking bans in the world. The Smoking Ordinance (Labor code 6404.5) of January 1998, extended the smoking ban to bars, game rooms, bingo parlours, casinos, and other public locations in California, and made it the first state to outlaw smoking in all indoor public places. Similar legislation has been subsequently adopted in India, Ireland, Malta, New Zealand (2004), Norway, and South Africa (2000). It is expected that smoking bans will be adopted in several other European countries in the near future, although the introduction of laws that prohibit smoking have often been highly contested. ${ }^{2}$

Environmental tobacco smoke (ETS) is an air pollutant made up of a complex mixture of around 4000 chemicals, some 50 of which are carcinogens. ${ }^{3}$ Exposure to ETS is causally associated with several adverse health effects, including lung cancer and heart disease in adults, exacerbation of asthma, lower respiratory illnesses, ear infections, and other diseases in children and infants. ${ }^{4-6}$ A recent report of the European Respiratory Society estimates that a total of 80000 adults in Europe in 2002 died from exposure to ETS, including 7000 subjects between 20-64 years of age who were exposed at work (2800 non-smokers). ${ }^{7}$

Hospitality venues where smoking is permitted are characterised by elevated ETS exposure. Siegel ${ }^{8}$ showed that ETS exposure in bar and restaurant employees is 1.5-4.4 times higher than in subjects who live with a smoker. Although the general public spends a limited amount of time in indoor public places, the resulting ETS exposure is relevant and health effects are also likely, and smoking bans seem to be associated with a rapid positive effect on ischaemic heart disease morbidity. ${ }^{9}$
Vapour phase nicotine and particulate matter $\left(\mathrm{PM}_{2.5}\right)$ are the most commonly used indicators to evaluate environmental exposure to ETS. ${ }^{11}$ Numerous studies have shown that tobacco smoke plays a major part in determining the concentration of particulate matter indoors. In addition, ETS is, like all other byproducts of combustion, made up of a considerable number of ultrafine particles (UFP), with a diameter $<0.1 \mu \mathrm{m}$, since the average aerodynamic diameter of ETS particles is approximately $0.2 \mu \mathrm{m} .{ }^{12}$ Ultrafine particles are an important cause of adverse effects as a consequence of their large total surface, their large alveolar deposition, inflammatory capability, and their possibility to translocate in the general circulation. ${ }^{13}$ Main indoor sources of UFP are smoking, cooking, candles, and chemical reactions (for example, terpens and ozone). ${ }^{14}$ Nicotine is principally metabolised into cotinine by the liver; it has a half life of around 18 hours and is generally considered the best indicator of nicotine intake. ${ }^{15}$ Urinary cotinine levels correlate with levels of environmental nicotine and with self reported ETS exposure. ${ }^{16}$

The evidence of the health effects of airborne particles comes from several lines of scientific investigation, from cellular and animal studies to large epidemiological investigations. Health effects include premature mortality, cardiorespiratory morbidity, and lung cancer. The World Health Organization has recently issued a global update of the Air Quality Guidelines. ${ }^{17}$ The annual average guideline value of $10 \mu \mathrm{g} / \mathrm{m}^{3}$ for $\mathrm{PM}_{2.5}$ was chosen to represent the lower end of the range over which

Abbreviations: CIAA, Clean Indoor Air Act; ETS, environmental tobacco smoke; PM, particulate matter; RIA, radioimmunoassay; RSP, respirable suspended particle; UFP, ultrafine particle 
significant effects on survival have been observed. The 24 hour $\mathrm{PM}_{2.5}$ guideline is $25 \mu \mathrm{g} / \mathrm{m}^{3}$. While there is considerable toxicological evidence of potential detrimental effects of ultrafine particles on human health, the existing body of epidemiological evidence was insufficient to reach a conclusion on the exposure-response relation to ultrafine particles and no recommendation was provided in the guideline for concentrations of ultrafine particles.

In order to evaluate the efficacy of the new legislation in public indoor environments in Italy, we studied changes in environmental concentrations of fine and ultrafine particles, as well as urinary cotinine in employees of public establishments, before and after (in the third and 12th month) the implementation of the law banning smoking.

\section{MATERIALS AND METHODS}

We measured exposure to environmental tobacco smoke by determining $\mathrm{PM}_{2.5}$ and the number of ultrafine particles in 40 establishments in the city of Rome (14 bars, six fast food restaurants, eight restaurants, six video game parlours, six pubs). The 40 locations were selected randomly from the official list of businesses in the western part of the city (Health District D, about 400000 inhabitants). The venues' owners were contacted by the regional health authority to request participation in the study. Baseline measurements of the environment were taken in November/December 2004 (before the law was in effect). In March/April 2005, and November/ December 2005 (after the law was in effect) the comparison measurements were taken again, without warning and during peak business hours. To increase the statistical efficiency and avoid a "learning effect," the number of locations studied was constant (40), but $50 \%$ of them were rotated out of the study for each successive measurement, and replaced with other establishments.

$\mathrm{PM}_{2.5}$ was measured with a real time aerosol monitor (DustTrak, Model 8520 TSI), equipped with a sampling nozzle to collect fine particles $\left(\mathrm{PM}_{2.5}\right)$. In the same establishments, ambient ultrafine particles were counted using a condensation particle counter: P-Trak Monitor (Mod. 8525 UPC TSI). At the same time, continuous measurements were taken of temperature, relative humidity, $\mathrm{CO}_{2}$, and air velocity (with Q-Trak Plus TSI). A survey of all these parameters was taken in the outside environment for purposes of comparison. The instruments took measurements every 10 seconds, and recorded the average reading every minute, in both smoking and non-smoking areas. Every day the instruments were recalibrated (to zero). Instruments were positioned inside, an average height of 0.8 metre above the tables and at least 3 metres from the entrance, in the centre when possible, and at least 2 metres from any potential pollutant source (gas stove, espresso machine, grill). The total measurement time was 20 minutes. Other variables recorded included size of location (square metres), air ventilation (natural or mechanical), smoking regulations, the presence of ashtrays and smokers, and the number of employees and customers present. Outdoor measurements of $\mathrm{PM}_{2.5}$ and UFP counts were taken nearby, 0.8 metre off the ground, and weather and traffic conditions were recorded.

$\mathrm{PM}_{2.5}$ measurements with DustTrak were later gravimetrically calibrated based on empirically derived correction equations. For one month in winter and one month in summer, in two environments, one reserved for smokers and the other for non-smokers, $\mathrm{PM}_{2.5}$ measurements were taken both with DustTrak and an active air pump (Skypost PM TCR-Tecora) with an air flow of $2.3 \mathrm{~m}^{3} / \mathrm{h}$ conforming to specified European protocols for measuring $\mathrm{PM}_{2.5} \cdot{ }^{18}$ The particles were collected on a $47 \mathrm{~mm}$ filter membrane. Each measurement was conducted over 8 hours. The measurements were carried out daily, in two phases (first phase from 8.00-16.00, the second phase from 20.00-04.00). The mass concentration of particulate collected was determined by manual gravimetric method, using a Sartorius scale with a resolution of $1 \mu \mathrm{g}$, after the filters were pretreated for at least 48 hours at 50 (SD 5) RH\%, 293 (SD 1) K (in a room with controlled temperature and relative humidity). ${ }^{19}$ Based on the linear regression of $\mathrm{PM}_{2.5}$ concentrations measured with Dust Trak/manual gravimetric method (RFM), two correction equations were applied to the $\mathrm{PM}_{2.5}$ data: $\mathrm{x}=(\mathrm{y}+21.01) / 4.01$ for smoking environments $(\mathrm{y}=4.0132$ $(1.0544) \times-21.048(72.5159)) \quad R^{2}=0.7567$, and $x=(y+9.1) /$ 2.66 for smoke free environments $(y=2.6587$ $(0.1932) \times-9.108(3.8360)) R^{2}=0.917$.

All non-smoking employees of the 40 facilities were asked to provide a urine sample, contemporaneously with $\mathrm{PM}_{2.5}$ measurements. An interview was completed for each subject, on personal data and information to evaluate subjective exposure to passive smoke in the workplace and at home (presence of smoke, hours of exposure per week). Urine samples were stored at $-80^{\circ} \mathrm{C}$. Urinary cotinine was measured using radioimmunoassay (RIA), according to the method described by Van Vunakis et al. ${ }^{20}$ A cut-off of $100 \mathrm{ng} / \mathrm{ml}$ was employed to distinguish active smokers from non-smokers. Two subjects of the first phase were excluded from the analyses with cotinine levels of $>100 \mathrm{ng} / \mathrm{ml}$.

Arithmetic and geometric means were calculated. Levels of environmental and biological data from the three periods were compared with the Mann-Whitney test. The results were confirmed using separate linear regression analysis with the $\log$ transformation of $\mathrm{PM}_{2.5}$, UFP, and urinary cotinine as the dependent variable and an indicator variable for the three periods of the assessment as the independent variable. The data were analysed using Stata 8 software.

\section{RESULTS}

Table 1 reports concentration levels of $\mathrm{PM}_{2.5}$ measured indoors before and after the law (in the third and 12th month); values recorded outdoors are also reported. The indoor microclimatic parameters did not show significant differences over the three measurement periods, and the average temperature remained steady $\left(21^{\circ} \mathrm{C}\right.$ before, $20.8^{\circ} \mathrm{C}$ first post-law period, and $20.9^{\circ} \mathrm{C}$ second post-law period). In 40 establishments monitored before the law took effect, 17 (42.5\%) were completely non-smoking, 14 (35\%) allowed smoking anywhere, and nine (22.5\%) reserved separate smoking areas. The prohibition nonetheless was not enforced in about half of the venues (8/17) and, in particular, was not enforced in any of the video game parlours. The average $\mathrm{PM}_{2.5}$ value for all smoking areas before the smoking ban was $184.6 \mu \mathrm{g} / \mathrm{m}^{3}$ (95\% CI 104 to 264.8 ). The highest values were observed in pubs that allowed smoking (mean $368.1 \mu \mathrm{g} / \mathrm{m}^{3}, 95 \%$ CI 89.3 to 646.9 ). In the areas reserved for non-smokers before the ban, readings of $\mathrm{PM}_{2.5}$ showed a mean of $56.7 \mu \mathrm{g} / \mathrm{m}^{3}$ (95\% CI 34.9 to 78.5$)$, higher than the values found in the air measured directly outside (mean 24.6, $95 \%$ CI 19.9 to 29.4 ). Statistical significant reductions were found in average $\mathrm{PM}_{2.5}$ values: from a pre-law level of $119.3 \mu \mathrm{g} /$ $\mathrm{m}^{3}$, which fell to $38.2 \mu \mathrm{g} / \mathrm{m}^{3}$ and $43.3 \mu \mathrm{g} / \mathrm{m}^{3}$ after the ban took effect. A reduction in particles was observed even in businesses that had never allowed smoking. In restaurants, video game parlours and pubs, the reduction of $\mathrm{PM}_{2.5}$ concentrations was particularly strong. Outdoor $\mathrm{PM}_{2.5}$ concentrations were relatively stable and close to the values recorded at a fixed monitoring site located at the National Health Institute, in the centre of the city.

A reduction of UFP values was also observed, although not as notable as for fine particles. The particle number concentration 


\begin{tabular}{|c|c|c|c|c|c|}
\hline Location (n obs) & Mean & $95 \% \mathrm{Cl}$ & $\begin{array}{l}\text { Geometric } \\
\text { mean }\end{array}$ & $95 \% \mathrm{Cl}$ & $\begin{array}{l}\text { Mann-Whitney } \\
\text { test }\end{array}$ \\
\hline $\begin{array}{l}\text { Bars } \\
\text { Pre-law (14) }\end{array}$ & 46.8 & 30.2 to 63.5 & 39.6 & 28.0 to 56 & \\
\hline Post-law I (13) & 25.6 & 21.7 to 29.5 & 24.7 & 20.9 to 29.3 & $p<0.03$ \\
\hline Post-law II (15) & 33.7 & 23.9 to 43.5 & 29.9 & 22.5 to 39.6 & $p<0.19$ \\
\hline $\begin{array}{l}\text { Fast food restaurants } \\
\text { Pre-law (7) }\end{array}$ & 29.8 & 21.2 to 38.3 & 28.5 & 21.0 to 38.6 & \\
\hline Post-law I (6) & 31.7 & 21.5 to 42 & 30.6 & 22.4 to 41.7 & $p<0.72$ \\
\hline Post-law II (5) & 25.1 & 9.8 to 40.4 & 23.2 & 13.5 to 39.7 & $p<0.22$ \\
\hline $\begin{array}{l}\text { Restaurants } \\
\text { Pre-law (12) }\end{array}$ & 111.0 & 52.4 to 169.6 & 78.0 & 43.5 to 140.0 & \\
\hline Post-law I (8) & 60.9 & 8.8 to 112.9 & 46.5 & 26.2 to 82.6 & \\
\hline Post-law II (8) & 36.5 & 13.6 to 59.4 & 29.7 & 17.2 to 51.4 & $p<0.03$ \\
\hline $\begin{array}{l}\text { Video game parlours } \\
\text { Pre-law (8) }\end{array}$ & 150.1 & 84 to 216.2 & 128.0 & 74.4 to 220.2 & \\
\hline Post-law I (8) & 39.7 & 11.4 to 67.9 & 32 & 18.7 to 54.8 & $p<0.005$ \\
\hline Post-law II (9) & 65.7 & 34.5 to 96.9 & 56.1 & 35.4 to 88.8 & $p<0.02$ \\
\hline $\begin{array}{l}\text { Pubs } \\
\text { Pre-law (6) }\end{array}$ & 368.1 & 89.3 to 646.9 & 257.0 & 78.9 to 838 & \\
\hline Post-law I (5) & 39.8 & 25.5 to 54.0 & 38.6 & 27.4 to 54.4 & $p<0.03$ \\
\hline Post-law II (6) & 57.7 & 5.2 to 110.3 & 45.2 & 21.3 to 96.2 & $p<0.02$ \\
\hline $\begin{array}{l}\text { All venues } \\
\text { Pre-law (47) }\end{array}$ & 119.3 & 75.7 to 162.8 & 69.5 & 51.6 to 93.6 & \\
\hline Post-law I (40) & 38.2 & 27.5 to 48.8 & 32.3 & 27.4 to 37.9 & $p<0.005$ \\
\hline Post-law II (43) & 43.3 & 33.2 to 53.3 & 35 & 28.8 to 42.5 & $p<0.01$ \\
\hline $\begin{array}{l}\text { Outdoors } \\
\text { Pre-law (11) }\end{array}$ & 24.6 & 19.9 to 29.4 & 23.7 & 19.3 to 29.4 & \\
\hline Post-law I (11) & 20.8 & 15.16 to 26.5 & 19.2 & 14.4 to 25.6 & $p<0.31$ \\
\hline Post-law II (8) & 27.2 & 21.3 to 33 & 26.4 & 21.2 to 32.9 & $p<0.32$ \\
\hline
\end{tabular}

went from $76956 \mathrm{pt} / \mathrm{cm}^{3}$ to $38079 \mathrm{pt} / \mathrm{cm}^{3}(\mathrm{p}<0.0001)$ and then $51692(p<0.01)$ (table 2). It should be noted that outdoor concentrations of ultrafine particles were lower in the first postlaw period than in the pre-law survey but the concentrations were higher in the second post-law assessment, again following the pattern monitored at the fixed station. ${ }^{21}$

Thirty-nine subjects agreed to provide urine samples in the pre-law monitoring period (two were excluded), 23 in the third

Table 2 Levels of ultrafine particulate matter (UFP, pt $/ \mathrm{cm}^{3}$ ) measured inside and outside hospitality venues before and after the smoking ban in Rome

\begin{tabular}{|c|c|c|c|c|c|}
\hline UFP (n obs) & Mean & $95 \% \mathrm{Cl}$ & $\begin{array}{l}\text { Geometric } \\
\text { mean }\end{array}$ & $95 \% \mathrm{Cl}$ & $\begin{array}{l}\text { Mann-Whitney } \\
\text { test }\end{array}$ \\
\hline \multicolumn{6}{|l|}{ Bars } \\
\hline Pre-law (14) & 60998 & 37896 to 84099 & 48918 & 3223 to 74032 & \\
\hline Post-law I (13) & 28737 & 18919 to 38554 & 24036 & 16043 to 36013 & $p<0.02$ \\
\hline Post-law II (15) & 51069 & 31850 to 70287 & 38423 & 22689 to 65067 & $p<0.03$ \\
\hline \multicolumn{6}{|c|}{ Fast food restaurants } \\
\hline Pre-law (7) & 42078 & 19241 to 64914 & 34734 & 17698 to 68167 & \\
\hline Post-law I (6) & 33314 & 21843 to 44786 & 31502 & 20945 to 47380 & $p<0.39$ \\
\hline Post-law II (5) & 22333 & 6422 to 38244 & 19700 & 10118 to 38747 & $p<0.72$ \\
\hline \multicolumn{6}{|l|}{ Restaurants } \\
\hline Pre-law (12) & 81787 & 50600 to 112973 & 67080 & 42271 to 106450 & \\
\hline Post-law I (8) & 32575 & 16605 to 48544 & 28256 & 17357 to 45998 & $p<0.01$ \\
\hline Post-law II (8) & 55050 & 30072 to 80027 & 46591 & 26467 to 82014 & $p<0.01$ \\
\hline \multicolumn{6}{|c|}{ Video game parlours } \\
\hline Pre-law (8) & 53861 & 33296 to 74425 & 48013 & 30405 to 75819 & \\
\hline Post-law I (8) & 33148 & 11021 to 55274 & 25344 & 13328 to 48193 & $p<0.05$ \\
\hline Post-law II (9) & 37587 & 19523 to 55650 & 30363 & 16984 to 54279 & $p<0.05$ \\
\hline \multicolumn{6}{|l|}{ Pubs } \\
\hline Pre-law (6) & 176012 & 97836 to 254188 & 163433 & 104914 to 254592 & \\
\hline Post-law I (6) & 76998 & 18631 to 172628 & 50676 & 19205 to 133720 & $\mathrm{p}<0.02$ \\
\hline Post-law II (6) & 94585 & 9488 to 188220 & 57363 & 16882 to 194905 & $p<0.023$ \\
\hline \multicolumn{6}{|l|}{ All venues } \\
\hline Pre-law (47) & 76956 & 59723 to 65354 & 58590 & 46615 to 73642 & \\
\hline Post-law I (41) & 38079 & 25499 to 50658 & 29085 & 23341 to 36242 & $p<0.0001$ \\
\hline Post-law II (43) & 51692 & 38030 to 65354 & 37344 & 28724 to 65354 & $p<0.01$ \\
\hline \multicolumn{6}{|l|}{ Outdoors } \\
\hline Pre-law (11) & 35713 & 21381 to 50045 & 28793 & 17352 to 47779 & \\
\hline Post-law I (11) & 16963 & 10137 to 23790 & 14961 & 10648 to 21023 & $p<0.05$ \\
\hline Post-law II (8) & 40205 & 20236 to 60174 & 34311 & 20325 to 57920 & $p<0.6$ \\
\hline
\end{tabular}




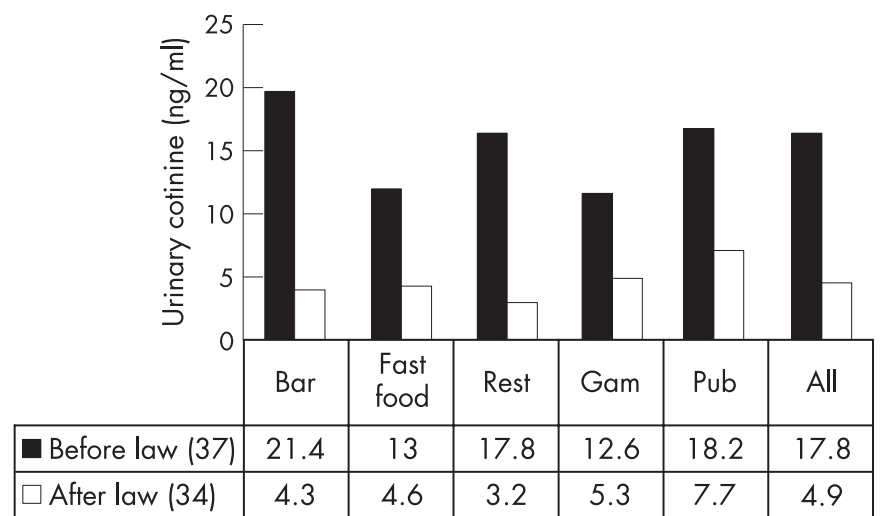

Figure 1 Concentration levels of urinary cotinine among employees of hospitality venues in Rome.

month post-law, and 11 in the 12th month post-law. The median age in the first period was 39 years, and 34 years in the post-law periods. The reduction in exposure observed in the biological readings (table 3) appears to be consistent with those found in the environmental measurements. Before the ban, the 37 subjects who were analysed (two excluded as smokers) presented a mean of urinary cotinine concentration of $17.8 \mathrm{ng} /$ $\mathrm{ml}$ (95\% CI 14 to 21.6 , SD 11.4 , median 14.2$)$. Three months after the ban, in the 23 subjects examined, the mean urinary cotinine concentration fell to $5.5 \mathrm{ng} / \mathrm{ml}$ (95\% CI 3.8 to 7.2 .6 ; SD 4.3, median 6.0). A year later there was a striking reduction in urinary cotinine (mean 3.7, 95\% CI 1.8 to 5.6; SD 2.8, median 4.0). The reduction was particularly notable in bars and restaurants (fig 1). Also, the analysis of the questionnaires showed a significant reduction of subjective exposure to ETS at the workplace in the post-law periods $(\mathrm{p}<0.0005)$.

When we considered the data from the three surveys, there was a statistically significant association between both $\mathrm{PM}_{2.5}$ and UFP levels and urinary cotinine concentrations. In particular, there was an increase of $0.75 \mathrm{ng} / \mathrm{ml}$ (95\% CI 0.4 to

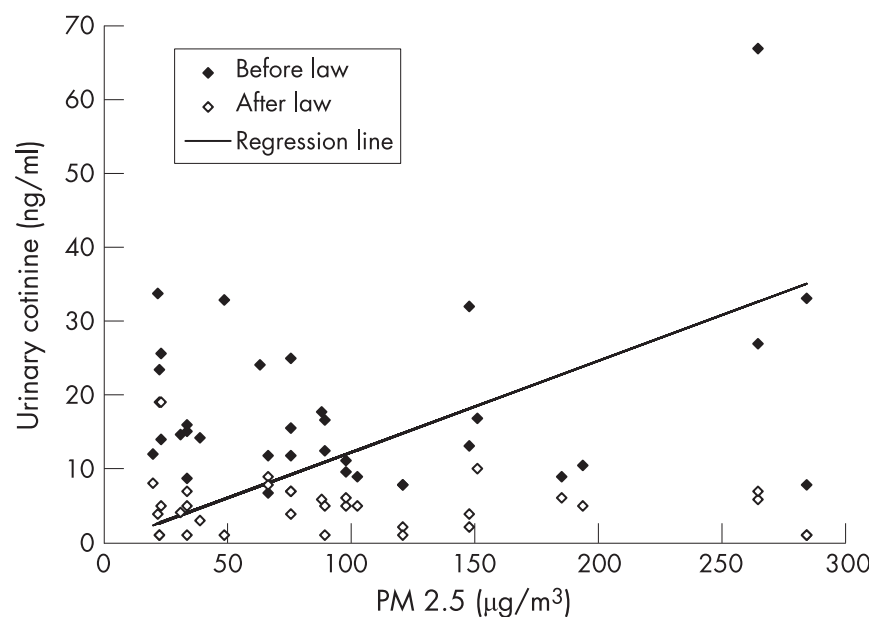

Figure 2 Association between indoor $\mathrm{PM}_{2.5}$ levels and urinary cotinine among employees.

1.1) in urinary cotinine for each $10 \mu \mathrm{g} / \mathrm{m}^{3}$ increase in $\mathrm{PM}_{2.5}$. The association between $\mathrm{PM}_{2.5}$ and urinary cotinine is shown in figure 2 .

\section{DISCUSSION}

We found that the application of the smoking ban led to a considerable reduction in exposure to indoor fine and ultrafine particles in public facilities. The results were confirmed with a simultaneous reduction of urinary cotinine.

Few studies have reported objective ETS exposure data from public locations, even fewer have used environmental $\mathrm{PM}_{2.5}$ and cotinine concentrations as the exposure indicator. Measurements taken in residences and offices ${ }^{22}$ indicate good correlation between ambient nicotine and ambient particulate concentrations. This has been particularly true in locations studied where (a) there is regular smoking, (b) microenvironments are in a steady state, and (c) the measurement periods

\begin{tabular}{|c|c|c|c|}
\hline & Men & Women & Total \\
\hline \multicolumn{4}{|l|}{ Pre-law } \\
\hline No of subjects & 29 & 8 & 37 \\
\hline Mean $(\mathrm{ng} / \mathrm{ml})$ & 17.8 & 17.9 & 17.8 \\
\hline $95 \% \mathrm{Cl}$ & 13 to 22.5 & 12.2 to 23.6 & 14 to 21.6 \\
\hline $\mathrm{SD}(\mathrm{ng} / \mathrm{ml})$ & 12.5 & 7.4 & 11.4 \\
\hline Median (ng/ml) & 13.2 & 15.2 & 14.2 \\
\hline Geometric mean (ng/ml) & 15 & 16.7 & 15.4 \\
\hline $95 \% \mathrm{Cl}$ & 12.3 to 18.5 & 11.7 to 23.6 & 13 to 18.3 \\
\hline \multicolumn{4}{|l|}{ Post-law I } \\
\hline No of subjects & 15 & 8 & 23 \\
\hline Mean $(\mathrm{ng} / \mathrm{ml})$ & 6.4 & 3.9 & 5.5 \\
\hline $95 \% \mathrm{Cl}$ & 4 to 8.8 & 2 to 5.7 & 3.8 to 7.2 \\
\hline $\mathrm{SD}(\mathrm{ng} / \mathrm{ml})$ & 4.3 & 2.2 & 3.9 \\
\hline Median (ng/ml) & 6.0 & 4.0 & 5.1 \\
\hline Geometric mean (ng/ml) & 5.2 & 3.2 & 4.4 \\
\hline $95 \% \mathrm{Cl}$ & 3.5 to 7.7 & 1.7 to 6 & 3.1 to 6.0 \\
\hline Mann-Whitney test & $p<0.0005$ & $p<0.003$ & $p<0.0001$ \\
\hline \multicolumn{4}{|l|}{ Post-law II } \\
\hline No of subjects & 5 & 6 & 11 \\
\hline Mean (ng/ml) & 3.0 & 4.3 & 3.7 \\
\hline $95 \% \mathrm{Cl}$ & 0.53 to 6.6 & 1.2 to 7.4 & 1.8 to 5.6 \\
\hline $\mathrm{SD}(\mathrm{ng} / \mathrm{ml})$ & 2.9 & 2.9 & 2.8 \\
\hline Median (ng/ml) & 1.0 & 4.5 & 4.0 \\
\hline Geometric mean (ng/ml) & 2.0 & 3.2 & 2.6 \\
\hline $95 \% \mathrm{Cl}$ & 0.59 to 7 & 1.2 to 8.7 & 1.4 to 4.9 \\
\hline Mann-Whitney test & $p<0.0001$ & $p<0.001$ & $p<0.0001$ \\
\hline
\end{tabular}


are significantly longer than necessary for smoke diffusion. ${ }^{12}$ $\mathrm{PM}_{2.5}$ is a widely accepted indicator to evaluate indoor air quality and is a valid exposure marker of ETS.

The real time measurements method (DustTrak) was well correlated with the gravimetric reference method, but it constantly overestimated $\mathrm{PM}_{2.5}$ levels (2.66 times higher), and the overestimation was even higher in the presence of ETS (4.01). The values measured with DustTrak, once corrected, resulted in line with measurements from other studies that used the gravimetric method. The mean (corrected) $\mathrm{PM}_{2.5}$ from the entire pre-law sample was $119.3 \mu \mathrm{g} / \mathrm{m}^{3}$. Recently, measurements with the gravimetric method showed average concentrations of $\mathrm{PM}_{2.5}$ to be $114.5 \mu \mathrm{g} / \mathrm{m}^{3}$ in the smoking sections of 59 pubs and bars. $^{23}$ Siegel reported a weighted respirable suspended particle (RSP) average of $117 \mu \mathrm{g} / \mathrm{m}^{3}$, based on 12 studies in restaurants. ${ }^{8}$ These values are analogous to those reported by Ellingsen ${ }^{24}$ for total particulate in restaurants in Norway $\left(115 \mu \mathrm{g} / \mathrm{m}^{3}\right)$. Outdoor concentration levels after correction also appear to be analogous to those calculated with the reference method for Rome.

Our data confirm the presence of elevated levels of ETS exposure in indoor hospitality venues, similar to those observed in England, ${ }^{23}$ in Ireland, ${ }^{28}$ in Norway, ${ }^{24}$ and in the US, ${ }^{25-27}$ before the smoking bans in restaurants and bars. Those who work in environments where there are no smoking restrictions for customers have three times higher exposure levels to ETS than employees of businesses where smoking is restricted to a special area. They also present cotinine levels that are much higher than employees of completely non-smoking businesses. ${ }^{29}$

As in Ireland, Norway, and the US, smoking bans in Italy also have drastically reduced ETS pollution. Our study showed that $\mathrm{PM}_{2.5}$ was reduced by two-thirds and urinary cotinine by $73 \%$. A statistically significant reduction in ETS pollution was also seen in establishments that already prohibited smoking. The significant reduction in air pollution is probably the result of both the rigorous manner in which the law was enforced, and of the great reduction in the number of businesses with smoking sections. In smoking sections, the reduction in the particulate concentrations was markedly smaller. One study that measured the changes in RSP levels in 20 restaurants and bars in New York reported an $84 \%$ decrease after the Clean Indoor Air Act (CIAA) was put into effect in July 2003.25 Similar results were obtained by Repace in Delaware. Examining the changes produced by the CIAA on the air quality, he found that RSP decreased by $91 \%$, contemporaneously to a $95 \%$ reduction of polycyclic aromatic hydrocarbons. ${ }^{26}$ In a cross sectional study of the hospitality industry, after the CIAA took effect in New York, a significant reduction was shown in urinary cotinine and ETS exposure levels, compared to pre-law levels. ${ }^{27}$ In particular, the proportion of subjects with undetectable levels of urinary cotinine increased from $3 \%$ to $62 \%$ after the law, while average values of urinary cotinine decreased from $4.93 \mathrm{ng} / \mathrm{ml}$ to $0.30 \mathrm{ng} / \mathrm{ml}$. These studies indicate that most $(70-90 \%)$ fine particulate concentrations indoors are related to cigarette smoke and that eliminating smoke significantly improves the quality of indoor air, with substantial reduction of health risks. Reductions similar to ours have been verified by using other markers, like salivary cotinine (reduced by $70 \%$ ) by Mulcahy et $a l^{28}$ in Ireland. In that study, self reported exposure to passive

\section{What is already known on this subject}

Some studies have suggested a positive impact of smoking bans on the reduction of ETS exposure. The studies have used airborne nicotine or particulate matter and urinary cotinine

\section{What this study adds}

In Italy, the smoking ban introduced in 2005 has produced a strong reduction of fine and ultrafine particles exposure in hospitality venues and a $73 \%$ reduction of urinary cotinine in employees. The study indicates a strong association between fine particulate matter from environmental smoking and urinary cotinine.

smoke showed a significant reduction from an average of 30 hours to zero hours and was associated with a great reduction $(83 \%)$ in concentrations of nicotine in the air, from an average of $35.5 \mathrm{mg} / \mathrm{m}^{3}$ to $5.95 \mathrm{mg} / \mathrm{m}^{3}{ }^{26}$ Ellingsen described exposure to nicotine and indoor particles, before and after the smoking ban was extended to include bars and restaurants in Norway. The mean concentrations of nicotine and total particulate (with gravimetric method) decreased from $28.3 \mu \mathrm{g} / \mathrm{m}^{3}$ (range $0.4-88.0$ ) and $262 \mu \mathrm{g} / \mathrm{m}^{3}$ (range 52-662), respectively, to $0.6 \mu \mathrm{g} / \mathrm{m}^{3}$ (range $0-3.7$ ) and $77 \mu \mathrm{g} / \mathrm{m}^{3}$ (range 0261) after the ban. Pearson's correlation between nicotine in the air and total particulate was very good $(0.86, \mathrm{p}<0.001$; $\mathrm{n}=48$ ). The geometric average of urinary cotinine concentrations was reduced from $9.5 \mu \mathrm{g} / \mathrm{g}$ creatinine (95\% CI 6.5 to 13.7 ) tol. $4 \mu \mathrm{g} / \mathrm{g}$ creatinine (95\% CI 0.8 to 2.5$)$ ( $\mathrm{p}<0.001$ ) in 25 nonsmokers. ${ }^{20}$ Similarly to Bates, ${ }^{29}$ our study also shows that employees of hospitality venues with smoking sections reserved for their customers are still considerably more exposed than those who work in non-smoking businesses.

Our data also suggest a relation between ETS pollution and ultrafine particles. Smoking is an important source of indoor UFP, but their number is also dependent on other sources like cooking appliances and burning candles ${ }^{30}$; this could explain the lower relative decrease of UFP when compared to PM 2.5 and urinary cotinine.

\section{CONCLUSION}

The introduction of the smoking ban in the workplace is a key tool for public health administrators determined to reduce passive smoke exposure in the general population. The examples available include Ireland, New York, New Zealand, Norway and now Italy. Such successes demonstrate that it is possible to significantly reduce ETS exposure. As a result, the incidence of smoking related diseases is bound to decrease, but the full effects have yet to be studied. ${ }^{31} 32$ An $11 \%$ reduction in hospitalisation rates for myocardial infarction among people under 60 years of age has been noted in one Italian region in the six month period following the smoking ban. ${ }^{33}$

Exposure reduction is predominantly associated with the elimination of smoking areas, while in smoking sections, in spite of air exchange and recycling systems, significant differences in air quality exist. The results of environmental and biological monitoring indicate that in facilities with smoking areas, a residual risk exists for the health of the employees.

\section{ACKNOWLEDGEMENTS}

We thank Fulvio Turrini, Maurizio Montopoli, Domenico Batisti, and Patrizia Compagnucci for their valuable collaboration, without which it would have been impossible to complete this study, Franco Taggi for his useful advice, and Margaret Becker for editorial assistance.

\footnotetext{
Authors' affiliations

Pasquale Valente, Irene Figà-Talamanca, University of Rome "La Sapienza", 5 Ple Aldo Moro, 00185 Rome, Italy

Francesco Forastiere, Monica Ferri, Carlo Perucci, Department of Epidemiology ASL Roma E, Rome, Italy
} 
Antonella Bacosi, Giorgio Cattani, Simonetta Di Carlo, Achille Marconi, Luigi Paoletti, Piergiorgio Zuccaro, Istituto Superiore di Sanità, Viale Regina Elena, 299, 00161 Rome, Italy

The study was approved by ethics committee of Istituto Superiore di Sanità.

\section{REFERENCES}

1 Legge 16 Gennaio 2003 n 3 Disposizioni ordinamentali in materia di pubblica amministrazione (Gazzetta Ufficiale n 15 del 20-1-2003- Suppl. Ordinario n 5).

2 Mclntosh K. UK stops short of outright smoking ban in enclosed public places. BMJ 2005;330:1468

3 National Institute of Occupational Safety and Health. Adverse health effects of smoking and the occupational environment. US DHEW CDC (NIOSH) Publication, 1979: $n, 79-122$

4 US Department of Health and Human Services (US DHHS) Surgeon General. The health consequences of involuntary exposure to tobacco smoke: a report of the Surgeon General, 27 June 2006. hittp://www.surgeongeneral.gov/library/ secondhandsmoke/.

5 International Agency for Research on Cancer (IARC). Tobacco smoke and involuntary smoking, Monographs Programme on the Evaluation of Carcinogenic Risks to Humans. Volume 83. Lyon: IARC, World Health Organization, 2004.

6 US Department of Health and Human Services (US DHHS). The health consequences of involuntary exposure to tobacco smoke: a report of the Surgeon General. Atlanta, Georgia: US Department of Health and Human Services, Centers for Disease Control and Prevention, Coordinating Center for Health Promotion, National Center for Chronic Disease Prevention and Health Promotion, Office on Smoking and Health, 2006, Available at http:// www.cdc.gov/tobacco/sgr/sgr_2006/index.htm.

7 European Respiratory Society. Lifting the smokescreen, 2006 www.ersnet.org.

8 Siegel M. Involuntary smoking in the restaurant workplace. JAMA 1993;270:490-3.

9 Sargent RP, Robert M Shepard R, et al. Reduced incidence of admissions for myocardial infarction associated with public smoking ban: before and after study. BMJ 2004;328:977-80.

10 Bartecchi C, Alsever RN, Nevin-Woods C, et al. Reduction in the incidence of acute myocardial infarction associated with a citywide smoking ordinance. Circulation. 2006;114: 1490-6, Epub 2006 Sep 25.

11 National Research Council. Environmental tobacco smoke-measuring exposures and assessing health effects. Washington, DC: National Academy Press, 1986.

12 Daisey J. M. Tracers for assessing exposure to environmental tobacco smoke: what are they tracing, Environ Health Perspect 1999; 107(Suppl 2):319-27.

13 Donaldson K, Stone V, Seaton A, et al. Ambient particle inhalation and the cardiovascular system: potential mechanisms. Environ Health Perspect 2001; 109(suppl 4):523-7.

14 Abt E, Suh HH, Catalano PJ, et al. Relative contribution of outdoor and indoor particle sources to indoor concentrations. Environ Sci Technol 2000;34:3579-87.

15 Jarvis MJ, Russell MAH, Benowitz NL, et al. Elimination of cotinine from body fluids: implications for noninvasive measurement of tobacco smoke exposure. Am J Public Health 1988;78:696-8.
16 Peterson EL, Johnson CC, Ownby DR. Use of urinary cotinine and questionnaires in the evaluation of infant exposure to tobacco smoke in epidemiologic studies. J Clin Epidemiol 1997;50:917-2.

17 Air Quality Guidelines. Global update 2005. Particulate matter, ozone, nitrogen dioxide and sulfur dioxide, EURO Nonserial Publication. http:// www.euro.who.int/Document/E87950.pdf.

18 EN 14907. Ambient air quality-standard gravimetric measurement method for the determination of the $\mathrm{PM}_{2.5}$ mass fraction of suspended particulate matter. European Standard, September, 2005.

19 Cattani G, Marconi A, Figà-Talamancae I, et al. Confronto tra misure di particelle fini mediante Dust Trak e sistema di prelievo di riferimento europeo per il PM 2.5. Risultati di campagne di misure estive ed invernali in ambienti interni con e senza fumatori. RisCh' 2006 II rischio chimico nei luoghi di lavoro: esperienze ed approfondimenti, Modena Atti II Volume 13 ottobre 2006;2:219-28.

20 Van Vunakis H, Gjika HB, Langone JJ. Radioimmunoassay for nicotine and cotinine. IARC Scientific Publications 1993;109:293-9.

21 Marconi A, Cattani G, Cusano M, et al. Two-years of fine and ultrafine particles measurements in Rome, Italy. J Toxicol Environ Health A 2007;70:213-21.

22 Jenkins RA, Palausky A, Counts RW, et al. Exposure to environmental tobacco smoke in sixteen cities in the United States as determined by personal breathing zone air sampling. J Expo Anal Environ Epidemiol 1996;6:473-502.

23 Gee IL, Watson FR, Carrington J, et al. Second-hand smoke levels in UK pubs and bars:do the English Public Health White Paper proposals go far enough? J Public Health 2006;1:17-23.

24 Ellingsen DG. Fladseth G, Daae HL, et al. Airborne exposure and biological monitoring of bar and restaurant workers before and after the introduction of a smoking ban. J Environ Monit 2006;3:362-8.

25 Centers for Disease Control and Prevention. Indoor air quality in hospitality venues before and after implementation of a clean indoor air law-western New York, 2003. MMWR Morb Mortal Wkly Rep 2004;53:1038-41.

26 Repace J. Respirable particles and carcinogens in the air of Delaware hospitality venues before and after a smoking ban. J Occup Environ Med 2004;46:887-905.

27 Abrams SM, Mahoney MC, Hyland A, et al. Early evidence on the effectiveness of clean indoor air legislation in New York State. Am J Public Health 2006;96:296-8.

28 Mulcahy M, Evans DS, Hammond SK, et al. Secondhand smoke exposure and risk following the Irish smoking ban: an assessment of salivary cotinine concentrations in hotel workers and air nicotine levels in bars. Tob Control 2005; 14:384-8.

29 Bates MN, Fawcett J, Dickson S, et al. Exposure of hospitality workers to environmental tobacco smoke. Tob Control 2002;11:125-9.

30 Afshari A, Matson U, Ekberg LE. Characterization of indoor sources of fine and ultrafine particles: a study conducted in a full-scale chamber. Indoor Air 2005; 15:141-50.

31 Samet JM. Smoking bans prevent heart attacks. Circulation 2006;114:1450-1

32 Menzies D, Nair A, Williamson PA, et al. Respiratory symptoms, pulmonary function, and markers of inflammation among bar workers before and after a legislative ban on smoking in public places. JAMA 2006;296:1742-8.

33 Barone-Adesi F, Vizzini L, Merletti F, et al. Short-term effects of Italian smoking regulation on rates of hospital admission for acute myocardial infarction. Environ Health J 2006;27:2468-72.

International Forum on Quality and Safety in Health Care

23-25 April 2008

Le Palais des Congrès de Paris

Call for Abstracts: Submission deadline 3 October 2007

Why submit an abstract?

- Your achievement showcased to key international opinion leaders

- Communicate your organisation's work

- Enhance your organisation's profile

- Network with others in your area/field

- Share your success, learn from your failures

For more details and to submit your abstract online visit internationalforum.bmi.com 